a carefully thought-out approach to understanding, by observation and experiment, the world of the mouse and the ways in which the mouse organises his world.

One of the most interesting aspects of this work is the way in which various individual mice emerged as personalities, so that the reader's feelings cannot help but be engaged, as were those of the writer, by the life and death problems faced by a mouse in a hostile universe. However, in spite of this, the account never ceases to be objective, which is the reason why this book can be so warmly recommended.

H. N. SOUTHERN

\title{
The Tuatara, Lizards and Frogs of New Zealand, by Richard Sharell. Collins, 30s.
}

The first book on the reptiles and amphibians of New Zealand, this is a useful guide for both professional and amateur naturalist. Well written and illustrated with over 50 colour photographs, the majority by the author, it contains a wealth of scientific detail which is easily understood by the layman, and much of it the result of the author's own experience in the field. The chapters on lizards and frogs, in which each specimen has its own paragraph dealing with colouration and habitat, etc., are very useful for identification.

Of particular interest to me were the two chapters on the tuatara, the lizard-like reptile that has remained virtually unchanged for the last two hundred million years, because I have been in charge of the only true pair of tuataras outside New Zealand; these are in the Jersey Zoo. In an interesting account of his stay on Stephen's Island, one of the twenty small islands off the coast of New Zealand which are the last stronghold of the tuatara, the author describes the habitat, feeding habits and even the hatching of the clutch of tuatara eggs. A short chapter describing the part played by reptiles in the legend and art of the Maori is most welcome-a very important aspect seldom mentioned in natural history books.

IOHN HARTLEY

\section{The Snow Bunting, by Desmond Nethersole-Thompson, Oliver} E Boyd, 45s.

Of biologists as well as economists and politicians it can be said that some know more and more about less and less, while others know less and less about more and more. As one of the latter category myself, I salute Desmond Nethersole-Thompson as a distinguished member of the former. He has devoted the greater part of his life to intensive study of a small number of breeding birds in one part of the Scottish Highlands. The fruits of this study appeared first in his New Naturalist monograph on the greenshank, and now in this thorough and detailed study of the life history and biology of the snow bunting. His subject is something of a mystery bird in the British avifauna; its exact breeding status has never been quite clear, for few ornithologists have been prepared to ascend the highest Scottish mountains year after year to check on its presence. The author and his son Brock are among those few, and they have come to the conclusion that Scottish snow-bunting breeding colonies are temporary affairs reflecting climatic conditions both in the Highlands and elsewhere. On the whole snow buntings are less likely to nest or attempt to nest in 
Scotland after a hard spring than they are after periods of severe weather in northern Europe.

This book takes its rightful place on the shelf alongside the best of the monographs of a single bird species that have been published in Britain in recent years.

RICHARD FITTER

\section{The Living Air, by Jean Delacour. Country Life, 45s.}

This fascinating account of a world which has passed, at least in Europe, will be read with nostalgic interest by those who have had the good fortune to see some of the private collections of animals and plants which existed even up to the last world war.

The author, born in Paris in the last years of the nineteenth century, began collecting birds at the age of ten and by the time he was fifteen had one of the largest collections then in existence as well as orchids and other exotic plants. These were maintained at his family's country estate at Villers-Bretonneux in Picardy. They were completely destroyed in the 1914-18 war, but re-established at Clères, Normandy, in 1918. For the next twenty years Dr. Delacour made expeditions all over the world, but especially to what was then Indo-China, to study the natural history of these countries, and produced a series of authoritative monographs.

During this period Clères became world famous, the collection of waterfowl alone being the most complete ever assembled. But this great zoological collection was almost wiped out in the 1939-45 war, and after the fall of France the author went to the USA, where he was later appointed Director of the Los Angeles County Museum. At the first opportunity he undertook, for the third time, to build up his collections, and to restore Clères to its position as the finest private zoo in the worldwith what success may be gathered from the description of it by the French author, Colette, Paradis Terrestre.

As the greatest living aviculturist and honorary member of innumerable zoological and ornithological societies, his autobiography provides a vivid picture of a master naturalist in the best sense of the word. Last but not least, he is an active campaigner for the conservation of wildlife and is the only surviving member of the group of naturalists who, forty-five years ago, founded the International Council for Bird Preservation, of which he is now President Emeritus.

EDWARD HINDLE

The Shell Bird Book, by James Fisher. Ebury Press and Michael Joseph, 25s.

The Shell Bird Book is crammed with information. No one does this kind of book better than James Fisher, for while it contains little that is new, it covers a great deal of ground that has not been explored in this compendious fashion before. One thinks immediately of the first chapter which begins in pre-history and gives an account of fossil remains found in this country.

Another useful chapter is on "Bird Protection," which is of deep concern to the author as indeed it should be to everyone. The development of the Royal Society for the Protection of Birds has been tremendous in the last decade and it is instructive to read about its origins (the campaign against the plumage trade) and its first subscription rate (twopence).

Of those who have watched, written about or otherwise interested 